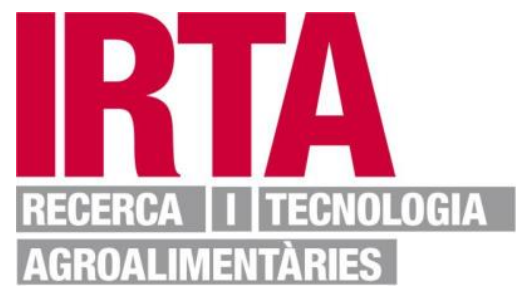

This document is a postprint version of an article published in Meat Science () Elsevier after peer review. To access the final edited and published work see https://doi.org/10.1016/j.meatsci.2019.02.014 


\title{
Effect of high pressure processing temperature on dry-cured hams with different textural characteristics
}

\author{
Coll-Brasas, E. ${ }^{1}$, Arnau, J. ${ }^{1}$, Gou, P. ${ }^{1}$, Lorenzo, J.M. ${ }^{2}$, García-Pérez, J.V. ${ }^{3}$ and \\ Fulladosa, E. ${ }^{1}$ \\ ${ }^{1}$ IRTA, XaRTA, Food Technology, Finca Camps i Armet, E-17121 Monells, Girona, Catalonia \\ ${ }^{2}$ CTC, Centro Tecnológico de la Carne de Galicia. Avenida de Galicia 4, Parque Tecnolóxico de Galicia, 32900 San \\ Cibrao das Viñas, Ourense. \\ ${ }^{3}$ UPV, Universitat Politècnica de València, Grupo de Análisis y Simulación de Procesos Agroalimentarios (ASPA). \\ Departamento Tecnología de los Alimentos. Camí de Vera, s/n, 46022 València, València.
}

\begin{abstract}
High pressure processing is mainly used to eliminate pathogenic microorganisms and extend the shelf-life of dry-cured hams, but it also modifies its texture. These changes might be different depending on the initial textural characteristics. In this study, texture, colour and colour stability were evaluated after pressurization at $600 \mathrm{MPa}$ during 6 min at $7{ }^{\circ} \mathrm{C}, 20^{\circ} \mathrm{C}$ and $35^{\circ} \mathrm{C}$ in samples with different textural characteristics (no pastiness, medium and high pastiness groups). HP treatments produced an increase of hardness $\left(\mathrm{F}_{0}\right)$ and lightness $\left(\mathrm{L}^{*}\right)$ values and a decrease of softness/pastiness $\left(\mathrm{Y}_{2}\right.$ and $\left.\mathrm{Y}_{90}\right)$ and redness $\left(\mathrm{a}^{*}\right)$ values at any processing temperatures. However, the increase of $\mathrm{F}_{0}$ and $\mathrm{L}^{*}$ values was more pronounced in non-pasty samples. In samples with high pastiness and softness, HP processing at high temperature $\left(35^{\circ} \mathrm{C}\right)$ reduced the intensity of pastiness. However, texture of hams with non-pasty texture might be negatively affected. Therefore, the optimal temperature of HP processing depends on the textural characteristics of dry-cured hams.
\end{abstract}

Key words - Dry-cured ham, colour, defective textures, pastiness, high pressure, temperature.

\section{Introduction}

Dry-cured ham is appreciated by consumers because of its flavour and texture characteristics. The main texture defects are excessive softness (Arnau, Guerrero, \& Sárraga, 1998; Parolari, Virgili, \& Schivazappa, 1994; Virgili, Parolari, Schivazappa, Bordini, \& Volta, 1995) and pastiness which are mainly related to raw material properties (García-Rey, García-Garrido, Quiles-Zafra, Tapiador, \& Luque de Castro, 2004; Schivazappa et al., 2002) and processing conditions (Ruiz-Ramírez, Serra, Arnau, \& Gou, 2005). Proteolysis activity contributes to texture development by breakdown of the muscle structure (Monin et al., 1997; Sentandreu, Coulis, \& Ouali, 2002), to taste through the generation of small peptides and free amino acids and to aroma by further degradation of some free amino acids (Toldrá \& Flores, 1998). However, when the extent of proteolysis is exceeded, the structure is severely damaged and unpleasant textures appear (Arnau et al., 1998; Toldrá, 2006). This defect occurs with an incidence 
of $12 \%$ in hams with a standard salt content, and increases when salt content is reduced (Tapiador Farelo \& García Garrido, 2003). Some works aimed to characterize and classify sliced ham according to textural characteristics using non-destructive technolgies based on infrared (García-Rey, García-Olmo, Pedro, Quiles-Zafra \& Castro, 2005; Ortiz, Sarabia, García-Rey \& Castro, 2006) and X-rays (Fulladosa et al., 2018) have been reported, but more work is need before its implementation at industry level.

Colour is another important attribute which also determines quality and consumer's acceptability. In cured meats, in which curing salts are used, many reactions occur leading to the formation of nitrosyl-myoglobin, the pigment which is responsible of the reddish colour of the cured meat products (Cassens, Greaser, Ito, \& Lee, 1979). However, colour modifications of the product during storage or high pressure processing can occur (Clariana et al., 2011; Fuentes, Ventanas, Morcuende, Estévez, \& Ventanas, 2010; Ha, Dunshea, \& Warner, 2017).

High pressure (HP) treatments are currently being used to eliminate pathogenic microorganisms and to extend the product shelf-life (Aymerich, Picouet, \& Monfort, 2008; Garcia-Gil et al., 2014). However, pressure treatments affect quality characteristics such as texture, colour (increasing lightness $\left(\mathrm{L}^{*}\right)$ values and decreasing redness (a*) values (Clariana et al., 2011; Fuentes, Utrera, Estévez, Ventanas, \& Ventanas, 2014; Fuentes et al., 2010; E Fulladosa, Sala, Gou, Garriga, \& Arnau, 2012; Ha et al., 2017)) and, potentially, the aroma and taste (increasing rancid odour and saltiness perception) (Andrés, Moller, Adamsen, \& Skibsted, 2004; Campus, Flores, Martinez, \& Toldrá, 2008; Cheftel \& Culioli, 1997; Lorido, Estévez, Ventanas, \& Ventanas, 2015; Martínez-Onandi, Rivas-Cañedo, Nuñez, \& Picon, 2016). A decrease of the incidence and of the intensity of defective textures such as pastiness has been also previously described (Fulladosa, Serra, Gou, \& Arnau, 2009; Lorido et al., 2015). These changes are different depending on the product characteristics. For instance, HP processing increased hardness, gumminess and stringiness and decreased adhesiveness and pastiness in dry-cured hams with $30 \%$ weight loss, but the effect was lower when the same HP treatment was applied to dryer hams (50\% weight loss) (Fulladosa et al., 2012). Serra et al. (2007) also found that lightness observed in the Biceps femoris muscle increased when the HP treatment was applied to frozen green hams but not when it was applied to frozen hams at the end of the resting stage. Importance of the processing conditions has also been described. Picouet et al. (2012) found that the 
application of HP treatments using different pressures 300, 600 and $900 \mathrm{MPa}$ produced different ultrastructural changes on 15 months aged dry cured-hams by transmission electron microscopy (TEM) analysis. Garcia-Gil et al. (2014) also found that the application of HP treatments at $500 \mathrm{MPa}$ produced changes on microstructure of Biceps femoris and Semimembranosus muscles of dry-cured ham when using microcomputed tomography and scanning electron microscopy. Andrés, Adamsen, Moller, Ruiz, and Skibsted (2006) reported that the application of HP treatment at $400 \mathrm{MPa}$ resulted in discoloration (increase of lightness and a decrease of redness) and in an oxidative degradation of lipids in dry-cured Iberian ham during subsequent illuminated chill storage. Similarly, Campus et al. (2008) found that HP treatments above $300 \mathrm{MPa}$ affected the colour producing an increase of lightness and a decrease of redness on sliced and vacuum packaged dry-cured pork loin.

Previous studies carried out using different HP treatments at $600 \mathrm{MPa}$ in a range of initial temperatures (between 7.5 and $24,4{ }^{\circ} \mathrm{C}$ ) showed no significant differences on the inactivation of microorganisms with the increase of the initial temperature (Belletti, Garriga, Aymerich, \& Bover-Cid, 2013; Bover-Cid, Belletti, Garriga, \& Aymerich, 2012). However, the evaluation of the effect of HP processing temperature on texture and colour of samples with different texture characteristics has not been found in literature.

The aim of this work was to study the effect of HP processing at different temperatures $\left(7{ }^{\circ} \mathrm{C}, 20^{\circ} \mathrm{C}\right.$ and $\left.35^{\circ} \mathrm{C}\right)$ on instrumental and sensory texture, colour and colour stability of samples with different textural characteristics(samples with no-pastiness and with medium or high pastiness defect).

\section{Material and methods}

\subsection{Elaboration process}

An elaboration process specially designed to induce textural defects of different intensity in dry-cured hams was used. Two hundred raw hams with a $\mathrm{pH}$ in the Semimembranosus muscle at $24 \mathrm{~h}$ post mortem lower than 5.5 were obtained from a commercial slaughterhouse supplied with animals from crosses of Large White and Landrace breeds. Hams with this $\mathrm{pH}$ were selected because they are more prone to develop texture defects (Tabilo, Flores, Fiszman, \& Toldra, 1999). The pH 
determination was performed with a Crison Basic $\mathrm{pH}$ meter (Crison Instruments S.A., Barcelona, Spain). All hams were weighed (11.9 kg $\pm 1.1 \mathrm{~kg})$ and salted according to the traditional system with some modifications in order to induce pastiness defects. In brief, hams were manually rubbed with the following mixture ( $\mathrm{g} / \mathrm{kg}$ of raw ham): 0.15 of $\mathrm{KNO}_{3}, 0.15$ of $\mathrm{NaNO}_{2}, 1.0$ of dextrose, 0.5 of sodium ascorbate and 10 of $\mathrm{NaCl}$. Thereafter, the hams were pile salted at $3 \pm 2{ }^{\circ} \mathrm{C}$ and $85 \pm 5 \% \mathrm{RH}$ during 4 days $(\mathrm{n}=50)$, 6 days $(n=50), 8$ days $(n=50)$ or 11 days $(n=50)$ in order to obtain hams with different salt contents. After salting, hams were washed with cold water and dried at $3 \pm 2{ }^{\circ} \mathrm{C}$ and $85 \pm 5 \% \mathrm{RH}$ during 45 days (post-salting period), at $12 \pm 2{ }^{\circ} \mathrm{C}$ and $70 \pm 5 \% \mathrm{RH}$ until reaching a weight loss of $29 \%$. Hams were then vacuum packaged and kept at $30{ }^{\circ} \mathrm{C}$ during 30 days to induce proteolysis. Thereafter, hams continued the drying process at $12 \pm 2{ }^{\circ} \mathrm{C}$ and $65 \pm 5 \% \mathrm{RH}$ until reaching a weight loss of $34 \%$, vacuum packaged again and kept at $30{ }^{\circ} \mathrm{C}$ during 30 days. After this period, hams were dried until the end of process was reached (final weight loss of $36 \%$ ).

\subsection{Sampling procedure}

For all the hams ( $n=200)$, the aitch bone, the butt and the femur bone were excised and the cushion part, containing Biceps femoris (BF) muscle, was obtained and trimmed. Cushion part was then sampled as follows: Three consecutive1.5 mm-thick slices were prepared for an initial sensory characterization of all the samples. One $2 \mathrm{~cm}$-thick slice of each selected ham was prepared for instrumental texture and chemical characterization before HP treatment (CT-samples). Another consecutive $2 \mathrm{~cm}$-thick slice was prepared for instrumental texture analysis after the specific HP treatment (HPsamples). Seven $1.5 \mathrm{~mm}$ thick slices from each selected ham were prepared for sensory analysis and for instrumental colour evaluation: 3 slices before HP treatment (CTsamples), 3 slices after the specific HP treatment (HP-samples) and the last one for evaluation of instrumental colour stability after HP treatment. All slices were vacuum packed in individual plastic bags of polyamide/polyethylene (oxygen permeability of 50 $\mathrm{cm}^{3} / \mathrm{m}^{2} / 24 \mathrm{~h}$ at $23^{\circ} \mathrm{C}$ and water permeability of $2,6 \mathrm{~g} / \mathrm{m}^{2} / 24 \mathrm{~h}$ at $23^{\circ} \mathrm{C}$ and $85 \% \mathrm{RH}$, Sacoliva ${ }^{\circledR}$ S.L., Spain) and stored in a chamber at $4{ }^{\circ} \mathrm{C} \pm 2{ }^{\circ} \mathrm{C}$ until the treatment and/or analysis were performed. 


\subsection{Ham assignment to the different Texture groups and HP treatments}

In order to assign hams to the different Texture groups (TG) defined in the experimental design (Table 1), an initial sensory analysis of pastiness of BF muscle from all the hams $(n=200)$ was performed using the $1.5 \mathrm{~mm}$ thick slices. For all the hams, instrumental texture, colour and chemical analysis described in section 2.6 were also performed using the $2 \mathrm{~cm}$ thick slices (CT-samples) previously prepared $(\mathrm{n}=200)$.

After this initial characterisation, a total of 90 hams were selected and assigned to the three different Texture groups according to their pastiness perception. Texture groups were: no-pastiness group (NPG) $(\mathrm{n}=30$, sensory pastiness $<0.5, \mathrm{PI}<33.0 \%$ and $0.59<\mathrm{Y}_{90}<0.69$ ), medium pastiness group (MPG) ( $\mathrm{n}=30$, sensory pastiness between $0.5-$ 2.0 and $27.0 \%<\mathrm{PI}<40.0 \%$ and $\left.0.64<\mathrm{Y}_{90}<0.72\right)$, and high pastiness group (HPG) $(\mathrm{n}=30$, sensory pastiness $>2.0,36.0 \%<\mathrm{PI}<48.0 \%$ and $\left.0.66<\mathrm{Y}_{90}<0.75\right)$. Then, the 30 hams from each Texture group were randomly selected and uniformly distributed to each HP treatment described in the next section (10 for HP7; 10 for HP20 and 10 for HP35). Samples of each ham were analysed before HP treatment (CT-samples) and after the HP treatment. See experimental design in Table 1.

\subsection{High hydrostatic pressure treatments}

High-pressure treatments at $600 \mathrm{MPa}$ during 6 min were performed in a NC Hyperbaric WAVE 6000/120 equipment (NC Hyperbaric, Burgos, Spain) at $7{ }^{\circ} \mathrm{C}$ (HP7, temperature commonly used in industrial HPP treatments), $20{ }^{\circ} \mathrm{C}$ (HP20) or $35^{\circ} \mathrm{C}$ (HP35). Samples were tempered to the assigned temperature using a temperature control cabinet (Model EC-360, Radiber S.A., Barcelona, Spain) and submitted to HP treatment using water at the same temperature. Because there is an adiabatic increase of temperature during pressurization from approximately $3^{\circ} \mathrm{C} / 100 \mathrm{MPa}$ (US Food \& Drug Administration, 2014), which depends on the pressure applied but also on the initial sample temperature and product composition (Patazca, Koutchma, \& Balasubramaniam, 2007; Picouet et al., 2016), it is difficult to determine the achieved temperature for the samples for each treatment. However, it is estimated that HP treated samples achieved temperatures of 23 ${ }^{\circ} \mathrm{C}, 36{ }^{\circ} \mathrm{C}$ and $53{ }^{\circ} \mathrm{C}$ when performing $\mathrm{HP}$ treatment at $7{ }^{\circ} \mathrm{C}, 20{ }^{\circ} \mathrm{C}$ and $35{ }^{\circ} \mathrm{C}$, respectively (Koutchma, 2014). Instrumental texture, colour and sensory analysis of the selected hams was performed $(\mathrm{n}=90)$. 


\subsection{Instrumental texture}

From the $2 \mathrm{~cm}$ thick slices a minimum of six parallelepipeds were cut from BF muscle with the exact same dimensions $(2 \mathrm{~cm} \times 2 \mathrm{~cm} \times 1,5 \mathrm{~cm})$. The pieces were wrapped in plastic film to avoid drying and kept at $4^{\circ} \mathrm{C} \pm 2{ }^{\circ} \mathrm{C}$ during 24 hours for temperature stabilization in a temperature control cabinet (Model EC-360, Radiber S.A., Barcelona, Spain). A Stress Relaxation test was performed using a Texture Analyser (Zwick/Roell, testXpert II, V3.2, 1996-2010, Zwick GmbH \& Co. KG, Ulm, Germany) provided with $30 \mathrm{kN}$ load cell and a $60 \mathrm{~mm}$ compression plate. Samples were compressed to $25 \%$ of their original height, perpendicular to the muscle fibre bundle direction, at a crosshead speed of $5 \mathrm{~mm} / \mathrm{s}$ and at a temperature of $4{ }^{\circ} \mathrm{C} \pm 2{ }^{\circ} \mathrm{C}$.

The force decay or relaxation versus time $Y_{(t)}$ was calculated as follows:

$$
Y_{(t)}=\frac{F_{0}-F_{(t)}}{F_{0}}
$$

Where $F_{0}(\mathrm{~kg})$ is the initial force and $F_{(t)}$ is the force recorded after $t$ seconds of relaxation. The force decay at $2 \mathrm{~s}\left(\mathrm{Y}_{2}\right)$ and $90 \mathrm{~s}\left(\mathrm{Y}_{90}\right)$ were calculated (Morales et al., 2007). For each parameter, the average of the six samples was used for the statistical analysis (E Fulladosa et al., 2009; Garcia-Gil et al., 2014).

\subsection{Chemical analysis}

Chemical analysis were performed on the muscle used in instrumental texture analysis (CT-samples). Moisture content was determined by drying at $103 \pm 2{ }^{\circ} \mathrm{C}$ until a constant weight was reached AOAC (1990). Salt content was also determined according to ISO 1841-2 (1996) using a potentiometric titrator 785 DMP Titrino (Metrohm AG, Herisau, Switzerland) and results were expressed as percentage of $\mathrm{NaCl}$ on a dry-matter basis (DM). Non-protein nitrogen content (NPN) was determined by precipitation of proteins with trichloroacetic acid (Gáspár, 1984) followed by determination of the total nitrogen (TN) in the extract with the Kjeldahl method ISO 937 (1978). Proteolysis index (PI) was determined as a percentage of the ratio between NPN and TN (Careri et al., 1993; Schivazappa et al., 2002). All the analyses were done in duplicate.

\subsection{Instrumental colour}

Lightness $\left(\mathrm{L}^{*}\right)$, redness $\left(\mathrm{a}^{*}\right)$ and yellowness $\left(\mathrm{b}^{*}\right)$ was measured on dry-cured ham slices (CIE, 1976) using a colorimeter (Minolta Chroma Meter CR-400, Tokyo, Japan). The 
illuminant used was D65 with $2^{\circ}$. Colour was measured in triplicate on the surface of BF muscle avoiding zones with cracks and tyrosine crystals, before and after HP treatment immediately after opening the package. During the colour measurements, the background used was always the same, a white surface. Colour stability of HP treated samples was determined by measuring colour on the same slice immediately after HP treatment $(\mathrm{t}=0 \mathrm{~h})$ and after $4,7,22$ and 28 days of storage at $6{ }^{\circ} \mathrm{C} \pm 0.5{ }^{\circ} \mathrm{C}$ in $24 \mathrm{~h}$ light exposure, simulating the conditions of the showcase. Samples were vacuum packed immediately after each measure.

\subsection{Sensory analysis}

For the initial characterization, the pastiness perception in all the hams $(n=200)$ was performed. Pastiness were scored using an unstructured scale from 0 (very low) to 10 (very high). A total of 30 sessions were carried out by a three-member expert panel trained following ASTM (ASTM, 1981). In each session, six slices randomly selected were evaluated. The average score of the 3 experts for each sample was used for the statistical analysis.

In order to evaluate the effect of HP in the selected batch of hams $(n=90)$, a profile of different sensory attributes grouped in texture and flavour were assessed on fifteen hams randomly selected from each Texture group, before and after HP treatment. BF muscle of $1.5 \mathrm{~mm}$ thick slices was evaluated. The texture attributes were: pastiness (feeling of paste detected in hams with a high proteolytic index, similar to the 'mouthcoating' sensation produced by flour-water paste during the mastication process), saliva viscosity (refers to the feeling of viscous degree of saliva when flowing, after mastication), and stringiness (amount of fibres detected during chewing) as described by Guerrero, Gou, and Arnau (1999). The flavour attribute was saltiness (fundamental taste sensation elicited by $\mathrm{NaCl}$ ). Attributes were scored using an unstructured scale from 0 (very low) to 10 (very high). A total of thirteen sessions were carried out by a three-member expert panel trained following ASTM (ASTM, 1981). In each session, a pair of samples (control and HP treated) from each HP treatment were randomly selected and evaluated by all the panellists. The sample order, with respect to the HP treatment, was randomized within session, blocking the order of presentation and the first-order carryover effects (Macfie, Bratchell, Greenhoff, \& Vallis, 1989). The average score of the 3 experts for each sample was used for the statistical analysis. 


\subsection{Statistical analysis}

Data were analysed as a randomized unbalanced incomplete block, split-plot design. For all variables except colour stability, the statistical model included as fixed effects the Texture group ( $2 \mathrm{df})$, the HP treatment ( $3 \mathrm{df}$ ) and their interaction ( $6 \mathrm{df})$ and as random effects the hams nested within the Texture group ( $36 \mathrm{df}$; the error term for the main plot; used for testing the Texture group effect) and the residual error (30 df; the error term for the sub-plot; used for testing the HP and TGxHP interaction effects). Therefore, the statistical mixed model was:

$$
\mathrm{Y}_{\mathrm{ijk}}=\mu+(\mathrm{TG})_{\mathrm{i}}+\mathrm{h}_{\mathrm{j}: \mathrm{i}}+(\mathrm{HP})_{\mathrm{k}}+(\mathrm{TGxHP})_{\mathrm{ik}}+\mathrm{e}_{\mathrm{ijk}}
$$

where $Y_{\mathrm{ijk}}$ is the observed value (dependent variable); $\mu$ is the overall population mean; $(\mathrm{TG})_{\mathrm{i}}$ is the fixed effect of the $\mathrm{i}^{\text {th }}$ texture group; $\mathrm{i}=1,2,3 ; \mathrm{h}_{\mathrm{j}: \mathrm{i}}$ is the random effect of the $\mathrm{j}^{\text {th }}$ ham nested within the $\mathrm{i}^{\text {th }}$ texture group; $\mathrm{j}=1, \ldots, 10 ;(\mathrm{HP})_{\mathrm{k}}$ is the fixed effect of the $\mathrm{k}^{\text {th }}$ high pressure treatment, $\mathrm{k}=1, \ldots, 4$; $(\mathrm{TGxHP})_{\mathrm{ik}}$ is the fixed effect of the interaction between the $\mathrm{i}^{\text {th }}$ texture group and the $\mathrm{k}^{\text {th }}$ high pressure treatment; and $\mathrm{e}_{\mathrm{ijk}}$ is the random residual. PROC MIXED of SAS release 9.1 was used to solve the mixed effect models.

In order to study colour stability, time of exposure to light was included as fixed effects in the model when analysed separately for each HP treatment and Texture group. Differences between mean values were tested by means of Tukey's test $(p<0.05)$ used at the 5\% level. All the analysis were performed using the ANOVA procedure of SAS 9.3 statistical package (SAS release 9.1)

\section{Results and discussion}

\subsection{Characterization of non-HP treated samples}

The BF muscle samples assigned to the different Texture groups showed no significant differences for salt and water contents (Table 2). In contrast, as previously reported (Arnau et al., 1998; Toldrá, 2006), an increase of proteolysis index (PI) with the increase of the pastiness intensity was observed (Table 2). According to PI differences, a decrease of initial force $\left(\mathrm{F}_{0}\right)$, and an increase of the force decay ( $\mathrm{Y}_{2}$ and $\mathrm{Y}_{90}$ values) with the increase of the pastiness intensity was observed (Table 3), which agrees with Morales et al (2007). No significant differences for L* (lightness) and $\mathrm{a}^{*}$ (redness) between texture groups were detected (Table 4). 
Pastiness was the attribute used for the assignation of the hams to the different Texture groups, therefore, as expected, pastiness increased from the NPG to the HPG (Table 5). Saliva viscosity also increased, while stringiness decreased. The three attributes must be different expressions of the same texture defect. Although there is no significant difference in the $\mathrm{NaCl}$ content between texture groups ( $p>0.05)$, a significant decrease in saltiness was detected in samples with a defective texture (MPG and HPG samples) $(\mathrm{p}<0.05)$ (Table 5). A hypothesis to explain this fact could be the influence of the different saliva viscosity caused by the different texture and proteolysis index on the saltiness perception.

\subsection{Effect of HP temperature on texture and sensory properties of samples from different Texture groups}

In all Texture groups, an increase of $\mathrm{F}_{0}$ was produced by the HP treatments, showing a higher increase when processing at high temperatures (Table 3). Ma and Ledward (2004) also found that an increase in pressure up to $400 \mathrm{MPa}$ led to an increase in the instrumental hardness of raw beef. An increase in instrumental hardness, gumminess and chewiness with increasing pressure (above $150 \mathrm{MPa}$ ) was also reported after pressurization of HP-treated raw turkey samples (Villacís, Rastogi, \& Balasubramaniam, 2008). Tanzi et al. (2004) observed a significant increase in stringiness and consistency in Parma dry-cured ham after pressurization. These results are also in agreement with Fulladosa et al. (2009), who found that the HP treatment at $600 \mathrm{MPa}$ on restructured dry-cured hams increased hardness and decreased pastiness. Interestingly, in the present study, a significant interaction between HP treatments and Texture group was detected $(\mathrm{P}<0.05)$. Increase of $\mathrm{F}_{0}$ was more pronounced in NPG samples (showing a mean increase of $1.8 \mathrm{Kg}$ ) rather than in medium (MPG) or high (HPG) defective ones (which showed a mean increase of 1.2 and $0.7 \mathrm{Kg}$, respectively). For example, when submitting samples to high pressure at $7^{\circ} \mathrm{C}$, an increase of $\mathrm{F}_{0}$ from 1.76 to $3.08 \mathrm{Kg}$ was observed in NPG samples whereas an increase from 0.53 to 1.05 $\mathrm{Kg}$ was observed in HPG samples. The reason could be that the effect of pressure is more severe/intensive in those proteins not affected by proteolysis (NPG samples) since they still have the native structure. Higher temperatures are needed to produce changes on proteins partially denatured (HPG samples) to create new rearrangements that increases $\mathrm{F}_{0}$. It must be remarked that, after $\mathrm{HP}$ treatments at $7{ }^{\circ} \mathrm{C}$ and $20{ }^{\circ} \mathrm{C}$, similar $\mathrm{F}_{0}$ values to the NPG control samples were achieved for MPG samples. Therefore, HP 
treatments at $7{ }^{\circ} \mathrm{C}$ and $20^{\circ} \mathrm{C}$ could be useful as a corrective action for the MPG samples. In contrast, a temperature of $35^{\circ} \mathrm{C}$ was needed to do a corrective action of HPG samples. The more pronounced effect of HP35 treatment on $\mathrm{F}_{0}$ in comparison to HP7 and HP20 may be due to the more severe changes in the myofibrillar proteins (protein denaturalization) and collagen shrinkage because of the high temperatures reached (Palka \& Daun, 1999; Pospiech, Greaser, Mikolajczak, Chiang, \& Krzywdzińska, 2002; Tornberg, 2005). It is known that the degree of the myofibrillar protein denaturation varies according to pressure, processing time, temperature, and $\mathrm{pH}$ (Garcia-Gil et al., 2014; Huppertz, Fox, \& Kelly, 2004). Besides, it has been reported that, when pressure is applied together with heat, modifications of ultrastructure are more intensive than when pressure or temperature are applied alone (Cheftel \& Culioli, 1997).

HP produced a significant decrease of $\mathrm{Y}_{2}$ and $\mathrm{Y}_{90}(\mathrm{p}<0.05)$ in all the studied temperatures. These texture modifications have been attributed to the aggregation of myosin molecules, which start to denature at pressures above $100 \mathrm{MPa}$ (Yamamoto, Yoshida, Morita, \& Yasui, 1994), and to form disulphide bonds at higher pressures (400 MPa) (Angsupanich, Edde, \& Ledward, 1999; Orlien, 2017). The decrease of force decay due to HP treatment was similar at any of the used temperatures, showing a decrease around 0.5 for $\mathrm{Y}_{2}$ and 0.4 for $\mathrm{Y}_{90}$ for all the temperatures used. High pressure produced a similar effect on $\mathrm{Y}_{2} / \mathrm{Y}_{90}$ regardless of the initial textural characteristics of the sample. A decrease of pastiness and saliva viscosity in samples subjected to all HP treatments in comparison to control samples for both MPG and HPG samples was found (Table 5). Both attributes were highly correlated $(\mathrm{r}=0.894, \mathrm{p}<0.05)$. On the contrary, stringiness increased after the application of high pressure. Defective samples (MPG and HPG) achieved a similar stringiness than NPG samples when HP treatment was applied at $7{ }^{\circ} \mathrm{C}$ in MPG samples and at 7 or $20{ }^{\circ} \mathrm{C}$ in HPG samples. However, the application of HP treatments in NPG samples doubled the score of stringiness regardless of the temperature applied. This fact was attributed to the non-damaged protein structure of NPG samples in which more important changes are produced during HP processing.

A significant increase of saltiness perception was produced by HP treatment in all the Texture groups, especially at $35^{\circ} \mathrm{C}$. This fact could even enhance taste, especially in salt reduced products. The observed increase agrees with Lorido et al. (2015), who reported that, after the application of HP treatment, saltiness intensity perception was 
potentiated and the persistence was higher in comparison to control ones in both Serrano and Iberian hams. In the present study, a clear increasing tendency of saltiness with HP temperature is observed, although only significant differences were found in NPG samples treated at $35^{\circ} \mathrm{C}$. Besides, a decrease of saltiness perception with the increase of the defective texture intensity was also found. Characteristics of the meat matrix plays an important role on the speed and amount of salt release to the saliva during chewing. As proteolysis index (highly correlated with pastiness defect) will extensible change protein structure of dry-cured hams, textural characteristics will also play a role in salt perception (Kuo \& Lee, 2014; Yucel \& Peterson, 2015; Lawrence et al., 2012). Differences on the total volatile compounds depending on the Texture group and the samples proteolysis index were also described by Pérez-Santaescolástica, Carballo, Fulladosa, Garcia-Perez, et al. (2018). High defective samples with excessive proteolysis index seems to be associated with negative effects on the taste and aroma of the dry-cured ham. Recent studies showed that moderate thermal treatments using ultrasounds (Pérez-Santaescolástica, Carballo, Fulladosa, Garcia-Perez José, et al., 2018) or HP processing at different temperatures (Pérez-Santaescolástica et al submitted) produced a significant reduction of the total volatile compounds content. For all these reasons, a consumer study would be necessary to evaluate the impact of these changes in taste and aroma on the product acceptability.

\subsection{Effect of HP temperature on colour and colour stability of samples from different Texture groups}

An increase of $\mathrm{L}^{*}$ values after HP processing in all the used temperatures was observed what agrees with the previous published studies (Andrés et al., 2004; Fuentes et al., 2010; Ha et al., 2017; Hughes, Oiseth, Purslow, \& Warner, 2014) (Table 4). This fact was attributed to the increase of reflected:absorbed ratio of light caused by the new rearrangement of proteins when denatured (Andrés et al., 2004; Clariana et al., 2011; Clariana, Guerrero, Sarraga, \& Garcia-Regueiro, 2012; Ottestad, Enersen, \& Wold, 2011). A significant interaction between HP treatment and Texture groups was found $(\mathrm{p}=0.003)$. Increase of $\mathrm{L}^{*}$ values was found to be more pronounced in NPG samples (mean increase of 6) which have a lower proteolysis index and a less damaged structure than in MPG samples (mean increase of 5) or in HPG samples (mean increase of 3.5) (Hughes et al., 2014; Palka \& Daun, 1999; Straadt, Rasmussen, Andersen, \& Bertram, 2007). Therefore, HPG samples could be submitted to HP at higher temperatures with 
similar effect on $\mathrm{L}^{*}$ values. This could permit an improvement of texture with a slight increase in the lightness of the product.

The decrease of $a^{*}$ values in HP treated samples was attributed to the partial denaturation of the globin part of nitrosylmyoglobin and to the formation of nitrosyl hemocromogen (NO-Heme) which was attributed to the protein and pigment denaturalization because of the combination of pressure and temperature (Carlez, Veciana-Nogues, \& Cheftel, 1995; Chensha, Jingzhi, Lizhen, \& Weiqing, 2016; Ha et al., 2017; Pegg \& Shahidi, 1996; Sun, Zhou, Xu, \& Peng, 2009). As in the case of lightness, redness $\left(\mathrm{a}^{*}\right)$ was not significantly affected when increasing the HP processing temperature, similarly for all the Texture groups (no significant interaction between Temperature treatment and Texture group, $\mathrm{p}>0.05$ ). Therefore, high pressure processing at $20^{\circ} \mathrm{C}$ or $35^{\circ} \mathrm{C}$ could be useful to improve texture without affecting the colour of the product with respect to processing at $7^{\circ} \mathrm{C}$.

Besides, colour during product shelf life was found to be stable after any of the studied HP treatments. Only a slight decrease of a* values were found between $0 \mathrm{~h}$ and 4 days of exposure to light for all the texture groups and HP treatments. However, no significant differences between 4, 7, 21 and 28 days of exposure were observed ( $>>0.05)$. Figure 1 shows the evolution of $\mathrm{a}^{*}$ for HP treatment at $7^{\circ} \mathrm{C}$, showing the samples HP treated at other temperatures a similar pattern. Cava, Ladero, González, Carrasco, and Ramírez (2009), after processing sliced dry-cured Iberian ham and loin using different $\mathrm{HP}$ treatment conditions at $200 \mathrm{MPa}$ and $300 \mathrm{MPa}$ during 15 and $30 \mathrm{~min}$, found a similar tendency in each treatment after 60 and 90 days of exposure to light. Results from this study suggest that neither the texture characteristics of the sample nor the temperature of the HP treatment influenced on the colour stability of sliced drycured ham.

Although HP treatments can produce changes on colour and other product characteristics, processing at $7^{\circ} \mathrm{C}$ is commonly used by industry to ensure safety and increase shelf life of dry-cured ham, and the resulting product is accepted by the consumers. However, the use of higher temperatures could produce more important changes in the $\mathrm{L}^{*}$ values of NPG samples. Due to the different effect of HP processing temperature on saltiness, texture and colour as a function of textural characteristics of the samples, the optimal HP processing temperature will depend on the samples texture. 
It must be remarked that a previous classification of the samples according to their texture characteristics using non-destructive technologies, as those proposed by Fulladosa et al. (2018) would be a useful tool to apply the optimal HP processing temperature to each product. For soft and pasty textures, a high temperature during HP processing would reduce the intensity of pastiness whereas for non-pasty textures, a low temperature would be recommended to avoid excessive hardness or stringeness.

\section{Conclusions}

HP treatment produces changes on texture and colour of dry-cured ham samples to a different extent depending on the processing temperature and textural characteristics of the samples. Therefore, textural properties of the product are important to define optimal HP processing conditions to improve texture without deteriorating colour. It would be necessary to study the impact of colour, saltiness perception and texture changes on consumers' acceptability.

\section{Acknowledgements}

This work was partially supported by INIA (n. RTA2013-00030-CO3-01) and Garantía Juvenil (PEJ-2014-A34573) from Ministerio de Economía y Competitividad, and CERCA programme from Generalitat de Catalunya. Acknowledgements are extended to INIA for financing the doctorate studies of Elena Coll Brasas CPD2015-0054 (FPI20150023). The authors would also acknowledge the contribution of Anna Austrich, Jeroni Durango, Carles Ramírez and Joaquim Arbonés.

\section{Reference}

Andrés, A. I., Adamsen, C. E., Moller, J. K. S., Ruiz, J., \& Skibsted, L. H. (2006). High-pressure treatment of drycured Iberian ham. Effect on colour and oxidative stability during chill storage packed in modified atmosphere. European Food Research and Technology, 222, 486-491.

Andrés, A. I., Moller, J. K. S., Adamsen, C. E., \& Skibsted, L. H. (2004). High pressure treatment of dry-cured Iberian ham. Effect on radical formation, lipid oxidation and colour. European Food Research and Technology, 219, 205-210.

Angsupanich, K., Edde, M., \& Ledward, D. A. (1999). Effects of High Pressure on the Myofibrillar Proteins of Cod and Turkey Muscle. Journal of Agricultural and Food Chemistry, 47(1), 92-99. doi:10.1021/jf980587p

AOAC (1990). Official method 950.46, Moisture in meat, B. Air drying. In K. Helrich (Ed.) (15th ed.). Official methods of analysis of the association of official analytical chemists (Vol. II, pp. 931), (1990).

Arnau, J., Guerrero, L., \& Sárraga, C. (1998). The effect of green ham $\mathrm{pH}$ and $\mathrm{NaCl}$ concentration on cathepsin activities and the sensory characteristics of dry-cured hams. J. Sci. Food Agric., 77, 387-392.

ASTM (1981). American Society for Testing and Materials. Guidelines for the selection and training of sensory panel members. ASTM STP 758, ASTM, Philadelphia, p. 33, (1981).

Aymerich, T., Picouet, P. A., \& Monfort, J. M. (2008). Decontamination technologies for meat products. Meat Science, 78(1-2), 114-129. doi:https://doi.org/10.1016/j.meatsci.2007.07.007

Belletti, N., Garriga, M., Aymerich, T., \& Bover-Cid, S. (2013). Inactivation of Serratia liquefaciens on dry-cured ham by high pressure processing. Food Microbiology, 35(1), 34-37. doi:https://doi.org/10.1016/j.fm.2013.03.001 
Bover-Cid, S., Belletti, N., Garriga, M., \& Aymerich, T. (2012). Response surface methodology to investigate the effect of high pressure processing on Salmonella inactivation on dry-cured ham. Food Research International, 45(2), 1111-1117. doi:https://doi.org/10.1016/j.foodres.2011.05.004

Campus, M., Flores, M., Martinez, A., \& Toldrá, F. (2008). Effect of high pressure treatment on colour, microbial and chemical characteristics of dry cured loin. Meat Science, 80, 1174-1181.

Careri, M., Mangia, A., Barbieri, A., Bolzoni, L., Virgili, R., \& Parolari, G. (1993). Sensory property relationships to chemical data of italian-type dry-cured ham. Journal of Food Science, 58(5), 968-972.

Carlez, A., Veciana-Nogues, T., \& Cheftel, J. C. (1995). Changes in colour and myoglobin of minced beef meat due to high pressure processing. Lebensmittel-Wissenschaft und-Technologie, 28(5), 528-538.

Cassens, R. G., Greaser, M. L., Ito, T., \& Lee, M. (1979). Reactions of nitrite in meat. Food Technology, 33, $46-57$.

Cava, R., Ladero, L., González, S., Carrasco, A., \& Ramírez, M. R. (2009). Effect of pressure and holding time on colour, protein and lipid oxidation of sliced dry-cured Iberian ham and loin during refrigerated storage. Innovative Food Science \& Emerging Technologies, $10(1), \quad 76-81$. doi:http://dx.doi.org/10.1016/j.ifset.2008.09.005

Cheftel, J. C., \& Culioli, J. (1997). Effects of high pressure on meat : a review. Meat Science, 46(3), 211-236.

Chensha, Y., Jingzhi, J., Lizhen, M., \& Weiqing, S. (2016). Effect of pH on the stability and molecular structure of nitrosyl hemochromogen. Food Chemistry, 196, 503-508.

Colorimetry, (1976).

Clariana, M., Guerrero, L., Sarraga, C., Diaz, I., Valero, A., \& Garcia-Regueiro, J. A. (2011). Influence of high pressure application on the nutritional, sensory and microbiological characteristics of sliced vacuum packed dry-cured ham. Effects along the storage period. Innovative Food Science \& Emerging Technologies, 12(4), 456-465. doi:10.1016/j.ifset.2010.12.008

Clariana, M., Guerrero, L., Sarraga, C., \& Garcia-Regueiro, J. A. (2012). Effects of high pressure application (400 and $900 \mathrm{MPa}$ ) and refrigerated storage time on the oxidative stability of sliced skin vacuum packed drycured ham. Meat Science, 90(2), 323-329. doi:10.1016/j.meatsci.2011.07.018

Fuentes, V., Utrera, M., Estévez, M., Ventanas, J., \& Ventanas, S. (2014). Impact of high pressure treatment and intramuscular fat content on colour changes and protein and lipid oxidation in sliced and vacuum-packaged Iberian dry-cured ham. Meat Science, 97(4), 468-474. doi:https://doi.org/10.1016/j.meatsci.2013.12.018

Fuentes, V., Ventanas, J., Morcuende, D., Estévez, M., \& Ventanas, S. (2010). Lipid and protein oxidation and sensory properties of vacuum-packaged dry-cured ham subjected to high hydrostatic pressure. Meat Science, 85(3), 506-514. doi:http://dx.doi.org/10.1016/j.meatsci.2010.02.024

Fulladosa, E., Austrich, A., Muñoz, I., Guerrero, L., Benedito, J., Lorenzo, J. M., \& Gou, P. (2018). Texture characterization of dry-cured ham using multi energy X-ray analysis. Food Control, 89, 46-53. doi:https://doi.org/10.1016/j.foodcont.2018.01.020

Fulladosa, E., Sala, X., Gou, P., Garriga, M., \& Arnau, J. (2012). K-lactate and high pressure effects on the safety and quality of restructured hams. Meat Science, 91(1), 56-61. doi:10.1016/j.meatsci.2011.12.006

Fulladosa, E., Serra, X., Gou, P., \& Arnau, J. (2009). Effects of potassium lactate and high pressure on transglutaminase restructured dry-cured hams with reduced salt content. Meat Science, 82(2), 213-218. doi:http://dx.doi.org/10.1016/j.meatsci.2009.01.013

Garcia-Gil, N., Santos-Garcés, E., Fulladosa, E., Laverse, J., Del Nobile, M. A., \& Gou, P. (2014). High pressure induces changes in texture and microstructure of muscles in dry-cured hams. Innovative Food Science \& Emerging Technologies, 22(0), 63-69. doi:http://dx.doi.org/10.1016/j.ifset.2014.01.004

García-Rey, R. M., García-Garrido, J. A., Quiles-Zafra, R., Tapiador, J., \& Luque de Castro, M. D. (2004). Relationship between $\mathrm{pH}$ before salting and dry-cured hamquality. Meat Science, 67, 625-632.

Gáspár, L. General laboratory methods. In I. Kerese (Ed.), Methods of protein analysis (pp. 30-86), (1984).

Guerrero, L., Gou, P., \& Arnau, J. (1999). The influence of meat pH on mechanical and sensory textural properties of dry-cured ham. Meat Science, 52, 267-273.

Ha, M., Dunshea, F. R., \& Warner, R. D. (2017). A meta-analysis of the effects of shockwave and high pressure processing on color and cook loss of fresh meat. Meat Science, 132(Supplement C), 107-111. doi:https://doi.org/10.1016/j.meatsci.2017.04.016

Hughes, J. M., Oiseth, S. K., Purslow, P. P., \& Warner, R. D. (2014). A structural approach to understanding the interactions between colour, water-holding capacity and tenderness. Meat Science, 98(3), 520-532. doi:https://doi.org/10.1016/j.meatsci.2014.05.022

Huppertz, T., Fox, P. F., \& Kelly, A. L. (2004). High pressure treatment of bovine milk: effects on casein micelles and whey proteins. Journal of Dairy Research, 71(1), 97-106. doi:10.1017/S002202990300640X

ISO 937. (1978). Meat and meat products. Determination of nitrogen content (Reference method). International Organization for Standardization, Geneva.

ISO 1841-2. (1996). Meat and meat products. Determination of chloride content - Part 2: Potentiometric method (Reference method). Geneva: International Organization for Standardization.

Koutchma, T. (2014). Adapting high hidrostatic pressure (HPP) for food processing operations: Elsevier.

Kuo, W.-Y., \& Lee, Y. (2014). Effect of Food Matrix on Saltiness Perception-Implications for Sodium Reduction. Comprehensive Reviews in Food Science and Food Safety, 13(5), 906-923. doi:doi:10.1111/15414337.12094

Lawrence, G., Buchin, S., Achilleos, C., Bérodier, F., Septier, C., Courcoux, P., \& Salles, C. (2012). In vivo sodium release and saltiness perception in solid lipoprotein matrices. 1. Effect of composition and texture. Agric. Food Chem, 60, 5287-5298. 
Lorido, L., Estévez, M., Ventanas, J., \& Ventanas, S. (2015). Comparative study between Serrano and Iberian drycured hams in relation to the application of high hydrostatic pressure and temporal sensory perceptions. LWT - Food Science and Technology, 64(2), 1234-1242. doi:http://dx.doi.org/10.1016/j.lwt.2015.07.029

Ma, H. J., \& Ledward, D. A. (2004). High pressure/thermal treatment effects on the texture of beef muscle. Meat Science, 68, 347-355.

Macfie, H. J., Bratchell, N., Greenhoff, K., \& Vallis, L. V. (1989). Designs to balance the effect of order of presentation and first-order carry-over effects in hall tests. Journal of Sensory Studies, 4(2), 129-148. doi:10.1111/j.1745-459X.1989.tb00463.x

Martínez-Onandi, N., Rivas-Cañedo, A., Nuñez, M., \& Picon, A. (2016). Effect of chemical composition and high pressure processing on the volatile fraction of Serrano dry-cured ham. Meat Science, 111, 130-138. doi:https://doi.org/10.1016/i.meatsci.2015.09.004

Monin, G., Marinova, P., Talmant, A., Martin, J. F., Cornet, M., Lanore, D., \& Grasso, F. (1997). Chemical and Structural Changes in Dry-cured Hams (Bayonne Hams) during Processing and Effectes of the Dehairing Technique. Meat Science, 47, 29-47.

Morales, R., Guerrero, L., Serra, X., \& Gou, P. (2007). Instrumental evaluation of defective texture in dry-cured hams. Meat Science, 76, 536-542.

Orlien, V. (2017). High pressure treatment and the effects on meat proteins. Medical Research Archives, 5(8).

Ortiz, M. C., Sarabia, L., García-Rey, R. \& Castro, M. D. L. (2006). Sensitivity and specificity of PLS-class modelling for five sensory characteristics of dry-cured ham using visible and near infrared spectroscopy. Analytica Chimica Acta, 558 125-131.

Ottestad, S., Enersen, G., \& Wold, J. P. (2011). Effect of Freezing Temperature on the Color of Frozen Salmon. Journal of Food Science, 76(7), S423-S427. doi:10.1111/j.1750-3841.2011.02313.x

Palka, K., \& Daun, H. (1999). Changes in texture, cooking losses, and myofibrillar structure of bovine M. semitendinosus during heating. Meat Science, 5l(3), 237-243. doi:http://dx.doi.org/10.1016/S03091740(98)00119-3

Parolari, G., Virgili, R., \& Schivazappa, C. (1994). Relationship between cathepsin B activity and compositional parameters in dry-cured hams of normal and defective texture. Meat Science, 38(1), 117-122. doi:https://doi.org/10.1016/0309-1740(94)90100-7

Patazca, E., Koutchma, T., \& Balasubramaniam, V. M. (2007). Quasi-adiabatic temperature increase during high pressure processing of selected foods. Journal of Food Engineering, 80(1), 199-205. doi:https://doi.org/10.1016/j.jfoodeng.2006.05.014

Pegg, R. B., \& Shahidi, F. (1996). A novel titration methodology for elucidation of the structure of preformed cooked cured-meat pigment by visible spectroscopy. Food Chemistry, 56(2), 105-110. doi:http://dx.doi.org/10.1016/0308-8146(96)00009-X

Pérez-Santaescolástica, C., Carballo, J., Fulladosa, E., Garcia-Perez José, V., Benedito, J., \& Lorenzo, J. M. (2018). Application of temperature and ultrasound as corrective measures to decrease the adhesiveness in dry-cured ham. Influence on free amino acid and volatile compound profile. Food Research International, 114, 140150. doi:https://doi.org/10.1016/j.foodres.2018.08.006

Pérez-Santaescolástica, C., Carballo, J., Fulladosa, E., Garcia-Perez, J. V., Benedito, J., \& Lorenzo, J. M. (2018). Effect of proteolysis index level on instrumental adhesiveness, free amino acids content and volatile compounds profile of dry-cured ham. Food Research International, 107, 559-566. doi:https://doi.org/10.1016/i.foodres.2018.03.001

Pérez-Santaescolástica, C., Carballo, J. , Fulladosa, E., Munekata, P.E.S., Bastianello Campagnol, P.C., Gómez, B \& Lorenzo, J.M. (2019). Influence of high-pressure processing at different temperatures on free amino acid and volatile compound profiles of dry-cured ham. Food Research International, 116, 49-56. doi:https://doi.org/10.1016/j.foodres.2018.12.039

Picouet, P. A., Hurtado, A., Jofré, A., Bañon, S., Ros, J.-M., \& Guàrdia, M. D. (2016). Effects of Thermal and Highpressure Treatments on the Microbiological, Nutritional and Sensory Quality of a Multi-fruit Smoothie. Food and Bioprocess Technology, 9(7), 1219-1232. doi:10.1007/s11947-016-1705-2

Picouet, P. A., Sala, X., Garcia-Gil, N., Nolis, P., Colleo, M., Parella, T., \& Arnau, J. (2012). High pressure processing of dry-cured ham: Ultrastructural and molecular changes affecting sodium and water dynamics. Innovative Food Science \& Emerging Technologies, 16, 335-340. doi:http://dx.doi.org/10.1016/j.ifset.2012.07.008

Pospiech, E., Greaser, M. L., Mikolajczak, B., Chiang, W., \& Krzywdzińska, M. (2002). Thermal properties of titin from porcine and bovine muscles. Meat Science, 62(2), 187-192. doi:http://dx.doi.org/10.1016/S03091740(01)00245-5

Ruiz-Ramírez, J., Serra, X., Arnau, J., \& Gou, P. (2005). Profiles of water content, water activity and texture in crusted dry-cured loin and in non-crusted dry-cured loin. Meat Science, 69, 519-525.

Schivazappa, C., Degni, M., Costa, L. N., Russo, V., Buttazoni, L., \& Virgili, R. (2002). Analysis of raw meat to predict proteolysis in Parma ham. Meat Science, 60, 77-83.

Sentandreu, M. A., Coulis, G., \& Ouali, A. (2002). Role of muscle endopeptidases and their inhibitors in meat tenderness. . Trends in Food Science and Technology, 13, 398-419.

Serra, X., Grèbol, N., Guàrdia, M. D., Guerrero, L., Gou, P., Masoliver, P., . . . Arnau, J. (2007). High pressure applied to frozen ham at different process stages. 2. Effect on the sensory attributes and on the colour characteristics of dry-cured ham. Meat Science, 75, 21-28. 
Straadt, I. K., Rasmussen, M., Andersen, H. J., \& Bertram, H. C. (2007). Aging-induced changes in microstructure and water distribution in fresh and cooked pork in relation to water-holding capacity and cooking loss - A combined confocal laser scanning microscopy (CLSM) and low-field nuclear magnetic resonance relaxation study. Meat Science, 75(4), 687-695. doi:https://doi.org/10.1016/j.meatsci.2006.09.019

Sun, W. Q., Zhou, G. H., Xu, X. L., \& Peng, Z. Q. (2009). Studies on the structure and oxidation properties of extracted cooked cured meat pigment by four spectra. Food Chemistry, 115(2), 596-601. doi:https://doi.org/10.1016/j.foodchem.2008.12.060

Tabilo, G., Flores, M., Fiszman, S. M., \& Toldra, F. (1999). Postmortem meat quality and sex affect textural properties and protein breakdown of dry-cured ham. Meat Science, 51, 255-260.

Tanzi, E., Saccani, G., Barbuti, S., Grisenti, M. S., Lori, D., Bolzoni, S., \& Parolari, G. (2004). High-pressure treatment of raw ham. Sanitation and impact on quality. Industria Conserve(79), 37-50.

Tapiador Farelo, J. \& García Garrido, J. A. (2003). Avances en la ciencia, tecnología y comercialización del jamón (Cojamón 2003, Cáceres) In (pp. 70-77).

Toldrá, F. (2006). The role of muscle enzymes in dry-cured meat products with different drying conditions. Trends in Food Science \& Technology, 17, 164-168.

Toldrá, F., \& Flores, M. (1998). The Role of Muscle Proteases and Lipases in Flavor Development During the Processing of Dry-Cured Ham. Critical Reviews in Food Science, 38(4), 331-352.

Tornberg, E. (2005). Effects of heat on meat proteins - Implications on structure and quality of meat products. Meat Science, 70, 493-508.

US Food \& Drug Administration. (2014). Kinetics of Microbial Inactivation for Alternative Food Processing Technologies -- High Pressure Processing. Science \& Research (Food). Retrieved from https://www.fda.gov/Food/FoodScienceResearch/ucm101456.htm

Villacís, M. F., Rastogi, N. K., \& Balasubramaniam, V. M. (2008). Effect of high pressure on moisture and $\mathrm{NaCl}$ diffusion into turkey breast. LWT- Food Science and Technology, 41, 836-844.

Virgili, R., Parolari, G., Schivazappa, C., Bordini, C. S., \& Volta, R. (1995). Effetto della materia prima sulla proteolisi e sulla consistenza del prosciutto crudo tipico. Effects of raw material on proteolysis and texture of typical parma ham. Industria Conserve, 70, 21-31.

Yamamoto, K., Yoshida, Y., Morita, J. i., \& Yasui, T. (1994). Morphological and Physicochemical Changes in the Myosin Molecules Induced by Hydrostatic Pressure. The Journal of Biochemistry, 116(1), 215-220. doi:10.1093/oxfordjournals.jbchem.a124496

Yucel, U., \& Peterson, D. G. (2015). Effect of Protein-Lipid-Salt Interactions on Sodium Availability in the Mouth and Consequent Perception of Saltiness: In Solutions. Journal of Agricultural and Food Chemistry, 63(34), 7487-7493. doi:10.1021/acs.jafc.5b0231 


\section{FIGURES}

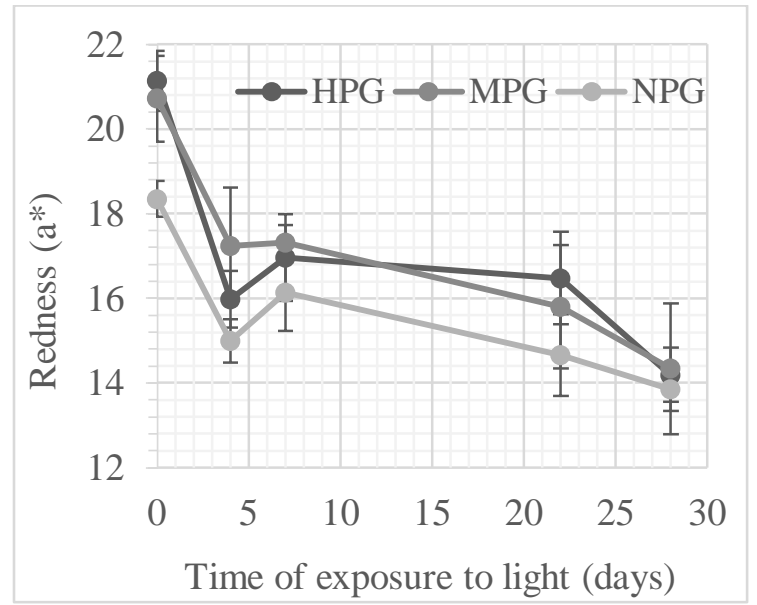

Figure 1: Colour stability of HP treated samples at $7{ }^{\circ} \mathrm{C}$ for the different Texture groups. NPG: Nonpastiness group; MPG: Medium pastiness group; HPG: High pastiness group. 


\section{TABLES}

Table 1: Distribution of hams $(n=90)$ according to different texture groups and HP treatments.

\begin{tabular}{|r|l|l|l|l|}
\hline \multirow{2}{*}{ Texture groups } & \multirow{3}{*}{ HP treatment } \\
\cline { 3 - 5 } & CT & HP7 & HP20 & HP35 \\
\hline NPG & 1 to 30 & 1 to 10 & 11 to 20 & 21 to 30 \\
\hline MPG & 31 to 60 & 31 to 40 & 41 to 50 & 51 to 60 \\
\hline HPG & 61 to 90 & 61 to 70 & 71 to 80 & 81 to 90 \\
\hline
\end{tabular}

NPG: No pastiness group; MPG: Medium pastiness group; HPG: High pastiness group. CT: Control samples (non HP-treated). HP treatments at different temperatures: $7^{\circ} \mathrm{C}(\mathrm{HP} 7) ; 20^{\circ} \mathrm{C}(\mathrm{HP} 20)$ and $35^{\circ} \mathrm{C}$ (HP35).

Table 2: Chemical characteristics (Mean \pm standard deviation) of Biceps femoris muscle according to the Texture group before HP treatment (Control samples).

\begin{tabular}{cccc}
\hline & \multicolumn{3}{c}{ Texture group } \\
\cline { 2 - 4 } & $\mathrm{NPG}$ & MPG & HPG \\
\hline $\mathrm{n}$ & 30 & 30 & 30 \\
$\mathrm{NaCl}(\%)$ & $4.80 \pm 0.72$ & $4.83 \pm 0.93$ & $4.71 \pm 0.87$ \\
$\mathrm{Moisture} \mathrm{( \% )}$ & $59.0 \pm 0.7$ & $58.7 \pm 1.0$ & $58.9 \pm 1.1$ \\
$\mathrm{PI}(\%)$ & $31.5 \pm 2.0^{\mathrm{c}}$ & $34.2 \pm 2.6^{\mathrm{b}}$ & $39.8 \pm 2.5^{\mathrm{a}}$ \\
\hline
\end{tabular}

$\overline{\mathrm{abc}}$ means within rows without a common letter are significantly different $(\mathrm{p}<0.05)$.

NPG: No pastiness group; MPG: Medium pastiness group; HPG: High pastiness group.

Table 3: Least square means of initial force $\left(\mathrm{F}_{0}, \mathrm{Kg}\right)$ and force decay at $2 \mathrm{~s}\left(\mathrm{Y}_{2}\right)$ and $90 \mathrm{~s}\left(\mathrm{Y}_{90}\right)$ on Biceps femoris muscle according to the interaction HP treatment $x$ Texture group.

\begin{tabular}{|c|c|c|c|c|c|}
\hline & \multirow[b]{2}{*}{ Treatment } & \multirow[b]{2}{*}{$\mathrm{n}$} & \multicolumn{3}{|c|}{ Texture group } \\
\hline & & & NPG & MPG & HPG \\
\hline \multirow[t]{2}{*}{$F_{0}$} & $\mathrm{CT}$ & 90 & $1.76^{\mathrm{a}}$ & $1.04^{\mathrm{a}}$ & $0.53^{\mathrm{a}}$ \\
\hline & HP7 & 30 & $3.08^{\mathrm{b}}$ & $2.00^{\mathrm{b}}$ & $1.05^{\mathrm{b}}$ \\
\hline $\mathrm{RMSE}=0.413$ & HP20 & 30 & $3.33^{\mathrm{b}}$ & $1.89^{\mathrm{b}}$ & $1.12^{\mathrm{b}}$ \\
\hline $\mathrm{p}<0.001$ & HP35 & 30 & $4.24^{\mathrm{c}}$ & $2.79^{c}$ & $1.65^{\mathrm{c}}$ \\
\hline \multirow[t]{2}{*}{$Y_{2}$} & $\mathrm{CT}$ & 90 & $0.362^{\mathrm{a}}$ & $0.408^{\mathrm{a}}$ & $0.432^{\mathrm{a}}$ \\
\hline & HP7 & 30 & $0.317^{\mathrm{b}}$ & $0.352^{\mathrm{b}}$ & $0.398^{b}$ \\
\hline $\mathrm{RMSE}=0.020$ & HP20 & 30 & $0.312^{\mathrm{b}}$ & $0.364^{\mathrm{b}}$ & $0.391^{\mathrm{b}}$ \\
\hline$p=0.255$ & HP35 & 30 & $0.305^{\mathrm{b}}$ & $0.342^{\mathrm{b}}$ & $0.389^{\mathrm{b}}$ \\
\hline \multirow[t]{2}{*}{$Y_{90}$} & $\mathrm{CT}$ & 90 & $0.649^{\mathrm{a}}$ & $0.686^{\mathrm{a}}$ & $0.697^{\mathrm{a}}$ \\
\hline & HP7 & 30 & $0.616^{\mathrm{b}}$ & $0.651^{\mathrm{bc}}$ & $0.681^{\mathrm{b}}$ \\
\hline $\mathrm{RMSE}=0.016$ & HP20 & 30 & $0.613^{\mathrm{b}}$ & $0.658^{\mathrm{b}}$ & $0.679^{\mathrm{b}}$ \\
\hline$p=0.084$ & HP35 & 30 & $0.606^{\mathrm{b}}$ & $0.638^{\mathrm{c}}$ & $0.669^{\mathrm{b}}$ \\
\hline
\end{tabular}

$\overline{a b c}$ means within columns without a common letter are significantly different $(p<0.05)$. NPG: No pastiness group; MPG: Medium pastiness group; HPG: High pastiness group. RMSE: root mean square error of the linear model. P: $p$ value of the interaction (HP treatment $\mathrm{x}$ Texture group) effect. CT: Control samples (non HP-treated). All the HP treatments were carried out at $600 \mathrm{MPa}$ during 6 minutes at different temperatures: at $7^{\circ} \mathrm{C}(\mathrm{HP} 7)$; at $20^{\circ} \mathrm{C}(\mathrm{HP} 20)$ and treatment at $35^{\circ} \mathrm{C}(\mathrm{HP} 35)$. 
Table 4: Least square means of $L^{*}$ and a* values colour on Biceps femoris muscle according to the interaction HP treatment $x$ Texture group.

\begin{tabular}{lllccc}
\hline & & & \multicolumn{3}{c}{ Texture group } \\
\cline { 4 - 6 } & Treatment & $\mathrm{n}$ & NPG & MPG & HPG \\
\hline $\mathbf{L}^{*}$ & CT & 90 & $38.63^{\mathrm{d}}$ & $37.44^{\mathrm{c}}$ & $38.13^{\mathrm{c}}$ \\
& HP7 & 30 & $41.89^{\mathrm{c}}$ & $40.21^{\mathrm{b}}$ & $40.55^{\mathrm{b}}$ \\
$\mathrm{RMSE}=1.372$ & HP20 & 30 & $47.19^{\mathrm{a}}$ & $44.46^{\mathrm{a}}$ & $43.68^{\mathrm{a}}$ \\
$\mathrm{p}=0.0068$ & HP35 & 30 & $45.18^{\mathrm{b}}$ & $43.18^{\mathrm{a}}$ & $42.58^{\mathrm{a}}$ \\
\hline $\mathbf{a}^{*}$ & CT & 90 & $20.07^{\mathrm{a}}$ & $21.26^{\mathrm{a}}$ & $20.82^{\mathrm{a}}$ \\
& HP7 & 30 & $18.23^{\mathrm{bc}}$ & $19.37^{\mathrm{b}}$ & $19.19^{\mathrm{bc}}$ \\
$\mathrm{RMSE}=1.541$ & HP20 & 30 & $18.33^{\mathrm{b}}$ & $18.78^{\mathrm{b}}$ & $20.90^{\mathrm{ab}}$ \\
$\mathrm{p}=0.2101$ & HP35 & 30 & $16.47^{\mathrm{c}}$ & $17.95^{\mathrm{b}}$ & $18.01^{\mathrm{c}}$ \\
\hline $\mathrm{abc}$ & & & &
\end{tabular}

$\overline{a b c}$ means within columns without common letter are significantly different $(\mathrm{p}<0.05)$. NPG: No pastiness group; MPG: Medium pastiness group; HPG: High pastiness group. RMSE: root mean square error of the linear model. P: $\mathrm{p}$ value of the interaction (HP treatment $\mathrm{x}$ defective level group) effect. CT: Control samples (non HP-treated). All the $\mathrm{HP}$ treatments were carried out at $600 \mathrm{MPa}$ during 6 minutes at different temperatures: at $7^{\circ} \mathrm{C}(\mathrm{HP})$ ) at $20^{\circ} \mathrm{C}$ (HP20) and treatment at $35^{\circ} \mathrm{C}(\mathrm{HP} 35)$.

Table 5: Least square means of sensory parameters evaluated (pastiness, saliva viscosity, saltiness perception and stringiness) on Biceps femoris muscle according to the interaction HP treatment $x$ Texture group.

\begin{tabular}{|c|c|c|c|c|}
\hline & \multirow[b]{2}{*}{ Treatment } & \multicolumn{3}{|c|}{ Texture group } \\
\hline & & NPG & MPG & HPG \\
\hline \multirow[t]{2}{*}{ Pastiness } & CT & 0.0 & $1.5^{\mathrm{a}}$ & $2.5^{\mathrm{a}}$ \\
\hline & HP7 & 0.0 & $0.8^{\mathrm{b}}$ & $1.7^{\mathrm{b}}$ \\
\hline RMSE $=0.461$ & HP20 & 0.0 & $0.4^{\mathrm{b}}$ & $1.7^{\mathrm{b}}$ \\
\hline $\mathrm{p}=0.009$ & HP35 & 0.0 & $0.3^{\mathrm{b}}$ & $1.3^{\mathrm{b}}$ \\
\hline \multirow[t]{2}{*}{$\begin{array}{c}\text { Saliva } \\
\text { viscosity }\end{array}$} & $\mathrm{CT}$ & 0.47 & $2.56^{\mathrm{a}}$ & $3.44^{\mathrm{a}}$ \\
\hline & HP7 & 0.03 & $1.19^{\mathrm{b}}$ & $2.86^{\mathrm{ab}}$ \\
\hline $\mathrm{RMSE}=0.436$ & HP20 & 0.07 & $0.74^{\mathrm{b}}$ & $2.29^{\mathrm{bc}}$ \\
\hline $\mathrm{p}<0.001$ & HP35 & 0.07 & $1.41^{\mathrm{b}}$ & $1.69^{\mathrm{c}}$ \\
\hline \multirow[t]{2}{*}{ Stringiness } & $\mathrm{CT}$ & $2.37^{\mathrm{b}}$ & $1.46^{\mathrm{c}}$ & $1.31^{\mathrm{b}}$ \\
\hline & HP7 & $4.77^{\mathrm{a}}$ & $2.59^{\mathrm{b}}$ & $2.53^{\mathrm{a}}$ \\
\hline RMSE $=0.593$ & HP20 & $4.83^{\mathrm{a}}$ & $3.69^{\mathrm{a}}$ & $2.35^{\mathrm{a}}$ \\
\hline $\mathrm{p}=0.059$ & HP35 & $4.77^{\mathrm{a}}$ & $3.41^{\mathrm{ab}}$ & $3.15^{\mathrm{a}}$ \\
\hline \multirow[t]{2}{*}{ Saltiness } & $\mathrm{CT}$ & $2.69^{c}$ & $1.96^{\mathrm{b}}$ & $1.53^{\mathrm{c}}$ \\
\hline & HP7 & $3.51^{\mathrm{ab}}$ & $2.19^{\mathrm{b}}$ & $1.51^{\mathrm{bc}}$ \\
\hline $\operatorname{RMSE}^{\mathrm{A}} 0.380$ & HP20 & $3.09^{b c}$ & $2.43^{\mathrm{ab}}$ & $2.28^{\mathrm{ab}}$ \\
\hline $\mathrm{p}=0.334$ & HP35 & $3.77^{\mathrm{a}}$ & $2.95^{\mathrm{a}}$ & $2.42^{\mathrm{a}}$ \\
\hline
\end{tabular}

$\overline{a b c}$ within columns and sensory parameters, means with different letters indicate significant differences $(p<0.05)$ within each experiment. NPG: No pastiness group; MPG: Medium pastiness group; HPG: High pastiness group. ${ }^{\text {A }}$ Root mean square error of the linear model. CT: Control samples (non HP-treated). All the HP treatments were carried out at $600 \mathrm{MPa}$ during 6 minutes at different temperatures: at $7^{\circ} \mathrm{C}(\mathrm{HP} 7)$; at $20^{\circ} \mathrm{C}(\mathrm{HP} 20)$ and treatment at $35^{\circ} \mathrm{C}(\mathrm{HP} 35)$. 